\title{
МОНГОЛ УЛСЫН ГАДААД БОДЛОГО БОЛОН \\ ХӨРШ УЛСЫН ХООРОНДОХ ХАРИЛЦАА
}

\author{
Ш.Амжилт БНХАУ.ӨМИС-ийн Монгол судлальн дээд сургууль багш \\ Э. Наран БНХАУ.ӨМИС-ийн Монгол судлальнн дээд сургууль проф,Доктор (Sc.D)
}

Товч агуулга: 2011 оны эхэнд, Монгол улс өөрийнхөө 20 шахам жил хэрэгжүүлсэн“Олон тулгуурт”гадаад бодлогын үзэл баримтлалдаа микро зохицуулалт хийж, АНУ зэрэг барууны улсуудыг “Гуравдагч хөрш” хэмээн хүлээн зөвшөөрсөн байна. Үнэндээ Монгол улсын ҮҮрдийн хөрш бол БНХАУ болон ОХУ юм.

1921 онд Монгол улс гадаад харилцааны байгууллагатай болсноос нааш дэлхийн 150 гаруй улстай элчин сайдын зэрэглэлийн гадаад харилцаа байгуулсан байна . Өнгөрсөн зууны 90-ээд он болтол 70 жилийн хугацаанд Монгол улс дан ганц ЗХУ-ыг л түшиглэн гадаад бодлого хэрэгжүүлсэн байна. Үндэсний ардчиллын эхний үед, 1994 онд Монгол улс шинэ “Олон тулгуурт” гадаад бодлогын үзэл баримтлал боловсруулжээ. “Олон тулгуурт” гадаад бодлогын цөм нь тэнцвэр болно, БНХАУ, ОХУ хоёр хөрш орон болон барууны нөлөө бүхий том гүрэнтэй тэнцүү зайтай тэнцвэрт гадаад бодлого хэрэгжүүлсэн байна. 2011 онд, Монгол улс өөрийнхөө 20 шахам жил хэрэгжүүлсэн гадаад бодлогын үзэл баримтлалдаа микро зохицуулалт хийж, АНУ зэрэг барууны улсуудыг “Гуравдагч хөрш” хэмээн хүлээн зөвшөөрсөн байна.

Гадаад бодлогодоо микро зохицуулалт хийж, “Гуравдагч хөрш”-ийг хүлээн зөвшөөрөв.

Монгол улс үндэсний өөрчлөн байгуулалт хийснээс нааш, түүний дотоодын байдал болон гадаад орчинд ихээхэн хувиралт гарсан байна. Дэлхий болон дотоодын байдлын хувиралттай зохицуулахын тулд, гадаад бодлогынхоо нэгдмэл чанар болон залгамж 
чанарыг хадгалж, “Олон тулгуурт” гадаад бодлогоо хувируулахгүй урьтал доор, Монгол улс “Гадаад бодлогын үзэл баримтлал”-даа засвар оруулсан байна. МУИХ-ын 2011 оны 10-р шийдвэрээр шинэ “Гадаад бодлогын үзэл баримтлал”-ыг баталсан байна.

Монгол улсын шинэ гадаад бодлогын үзэл баримтлалын гол чиглэл нь мөн ОХУ, БНХАУ хоорондын харилцааг нэгдүгээр чиглэл гэж үзсэн байна. ОХУ, БНХАУ-тай найрсаг харилцаатай байх нь Монгол Улсын гадаад харилцааны бодлогын эн тэргүүний зорилт мөн бөгөөд тэдгээр улстай бүхэлдээ тэнцвэртэй харилцаж, сайн хөршийн ёсоор өргөн хүрээтэй хамтын ажиллагаа хөгжүүлнэ. Чингэхдээ энэ хоёр улстай харилцаж ирсэн түүхэн уламжлал, эдийн засгийн хамтын ажиллагааны өвөрмөц онцлогийг харгалзах.

Гэхдээ түүний гадаад бодлогын хоёрдугаар чиглэлд ихээхэн хувиралт гарав. Тухайлбал АНУ, Япон, Европын холбоо, Энэтхэг, БНСУ, Турк зэрэг өрнө, дорнын улс, холбоотой “Гуравдагч хөрш”-ийн бодлогын хүрээнд түншлэлийн харилцаа, хамтын ажиллагааг өргөжүүлэн хөгжүүлэх болно. Энэ бол шинэ гадаад бодлогын үзэл баримтлалын хамгийн чухал нэмэлт өөрчлөлт оруулсан хэсэг, даруй Монгол улс анх удаа “Гуравдагч хөрш”-ийг хуулийн бичиг материалд бичин оруулж, Монгол улс “Гуравдагч хөрш” гэсэн энэхүҮ ухагдахууныг албан ёсоор хуулийн хэлбэр болгон тогтоосныг харуулж байна.

Монгол улс болон хөрш орны хоорондох харилцаа

Монгол улс бол ОХУ, БНХАУ-ын хооронд оршдог Азийн эх газрын улс, хоёрхон хөрш улстай. Хятад Орос хоёр хөрштэйгөө хэрхэн харилцах нь Монгол улсын оршин тогтнож хөгжихөд шууд холбоотой асуудал болно. Сүүлийн жилүҮдэд, Монгол улс болон БНХАУ, ОХУ-ын найрсаг харилцаа түргэн хөгжиж байна.

Нэг Монгол Оросын харилцаа

\section{1. Стратегийн түншлэлийн харилцаа}

Сүүлийн жилүүдэд, Орос Монголын төрийн лидерууд удаа дараа харилцан айлчилж, хоёр орны харилцаа тасралтгүй эрчимжиж байна. 2009 оны 8-р сард ОХУ-ын ерөнхийлөгч Медевидев Монгол улсад айлчилж байгаа үеэр хоёр тал 2003 онд байгуулсан Монгол 
Оросын найрсаг хөршийн уламжлалт харилцаагаа стратегийн түншлэлийн харилцаа болгон ахиулж, хоёр талаараа “Стратегийн түншлэлийн харилцаа хөгжүүлэх тухай тунхаг”-т гарын үсэг зурав. Энэ хугацаанд, Монгол Орос хоёр тал төмөр замын хамтарсан тээврийг эрчимжүүлэх, газар тариалан хөгжүүлэх, цөмийн эрчим хүчний хамтын ажиллагаатай холбогдох бичиг материалд гарын үсэг зурж, OХУ-аас Монголд техникийн боловсон хүчин бэлтгэж өгөх, хоёр орны агаарын тээврийн компанийн рейсийг нэмэгдүүлэх, хоёр орны хамтарсан Эрдэнэтийн зэс молибдены уурхай зэрэг хамтарсан аж ахуйн нэгжийн технологийн шэнэчлэлт зэрэг талын аль олон чухал хамтын ажиллагааны гэрээнд гарын үсэг зуржээ.

Мөн жил, ОХУ-ын ерөнхий сайд Путин Монголд айлчилж байгаа хугацаандаа байгуулсан чухал гэрээний нэг бол ОХУ-аас Монголд 7 тэрбум ам.долларын асар их хөрөнгө оруулалт олгож, түүнийг голдуу хоёр талын төмөр зам, ашигт малтмалын хамтын ажиллагаанд хэрэглэхээр амласан явдал болно.

2010 оны 12-р сард Монгол улсын ерөнхий сайд Батболд ОХУ-д айлчилж байхдаа ОХУ-ын ерөнхий сайд Путинтэй хэлэлцээ хийсний дүнд ОХУ-ын тал Монголын талын 180 сая шахам ам.долларын өрийг барагдуулахаар тогтссон байна. ОХУ Монгол улстай бүх талын хамтын ажиллагааны харилцаа байгуулж, бүх салбарт хамтарсан аж ахуйн нэгж байгуулахыг зорьж байна, Монгол улс бас ОХУ-ын гармаар дамжиж худалдаа хийж болно гэж Путин чухалчлан хэлжээ. Монгол Оросын лидеруудын удаа даараагийн уулзалт болон байгуулсан чухал гэрээнүүд нь Монгол улстай гадаад харилцаа сайжруулах ажлыг ОХУ өөрийн гадаад бодлогынхоо гол бодлогын нэг болгож, Монгол улс ОХУ-ын гадаад харилцааны төвд дахин буцаж очсоныг харуулж байна.

2. Цэрэг дайны аюулгүй байдлын хамтын ажиллагаа бол хоёр талын харилцааны чухал бүрэлдэхүун хэсэг мөн

Сүүлийн жилүүдэд, Орос болон Монгол улс батлан хамгаалалтын салбарын хамтын ажиллагаагаа сэргээж эрчимжүүлсэн байна. 2008 оны 4-р сард, ОХУ Монгол улсад 120 сая ам.долларын зэвсэг(1) хангахаар зөвшөөрч, тухайн жил хоёр тал ОХУ-аас Монголд 60 сая ам.долларын зэвсэг тоноглол хангах гэрээ байгуулав. Оросын тал бас Монголын армийн нисдэг тэрэг болон бусад зэвсэг тоноглолыг орчин үечийн зэвсэг тоноглол болгон өөрчлөн 
сайжруулж, Монголын армийн агаарын сэргийлэлтийн системийг орчин үеийн стандартад хүргэхээр амлажээ. 2009 оны 4-р сард, Монгол Орос “ОХУ болон Монгол улсын 2008-2012 он хүртэлх цэрэг дайны технологийн хамтын ажиллагааны дунд хугацааны төлөвлөгөө”(2)-нд гарын үсэг зурав. ОХУ-ын Батлан хамгаалах яам Цэргийн сургуульдаа Монголын цэрэг дайны боловсон хүчний бэлтгэж өгнө гэж ОХУ-ын Батлах хамгаaлах яамны сайд илэрхийлэв.

АНУ болон Монгол улс 2003 оноос нааш "Хааны хайлт” олон улсын цэргийн сорилт хийснээс нааш, 2008 оноос Монгол Орос хамтран Монголын нутаг дэвсгэрт “Дархан-1”, “Дархан-2” цэргийн сорилт хийсний дараа, 2010 оны 9-р сард ОХУ-ын нутаг дэвсгэр дээр “Дархан-3”(3) хамтарсан цэргийн сорилт хийжээ. Ингэснээр, Орос Монголын цэргийн сорилт нь дүрэмжсэн байна.

3. Эдийн засаг худалдааны харилцаа бол хоёр орны харилцааны суурь мөн Өнгөрсөн одоо гэсэнгүй, Монгол улсын эдийн засгийн хөгжил ОХУ-аас салж чадахгүй юм. Сүүлийн жилүүдэд, ОХУ-аас Монгол улсад хөнгөлөлттэй бодлого хэрэгжүүлэхийг дагаж, Монгол Оросын эдийн засаг худалдааны харилцаа түргэн хурдтай сэргэн хөгжиж байна.

2008 онд хоёр талын худалдааны хэмжээ 1.329 тэрбум ам.долларт хүрч, хоёр орны 2006 онд төлөвлөсөн таван жилийн хугацаанд хоёр талын худалдааны хэмжээг 1 тэрбум ам.долларт хүргэх гэсэн зорилтыг урьдчилан биелүүлсэн байна. Банк санхүүгийн хямралын үеиййн 2010 онд хоёр талын худалдааны хэмжээ мөн 1.17 тэрбум ам.долларт(4) хүрч, өнгөрсөн оны мөн үеийнхээс 40\% өссөн байна. ОХУ бол Монгол улсын хоёрдугаар том худалдааны түнш болон нэгдүгээр том импортлогч улс, Монгол улс газрын тосны бүтээгдэхүүнээ эртнээс аваад бүхнийг ОХУ-аас импортлоход түшиглэж иржээ. 2010 оны импортлосон газрын тосны бүтээгдэхүүн нь 800 шахам мянган тоннд хүрч, Монгол улсын импортын бүтээгдэхүүний 20.7\%-ийг эзэлж байна. 2011 оны 4-6 сард ОХУ-д шатахуун дутагдсанаас экспортыг хязгаарлах бодлого хэрэгжүүлснээс Монгол улсад дизель дутагдаж, хаврын тариалалт, зам тээвэр болон уул уурхайн олборлолт зэрэг салбарт шууд нөлөөлсөн байна. Хөрөнгө оруулалтын талаар, ЗХУ задарсны дараа ОХУ-ын Монголд оруулах хөрөнгө нь өнгөрсний монопол байр сууриа алдсан хэдий ч, ЗХУ-ын үед тусалж байгуулсан гурван том хамтарсан аж ахуйн нэгжийн бүтээгдэхүүний хэмжээ нь Монголын 
ДНБ-ий 40\%-ийг эзэлсэн хэвээр байж, бүтээгдэхүүний экспортын хэмжээ нь Монголын нийт экспортын хэмжээний 60\%-ийг зэлж байна. Хоёр талын төмөр зам, ашигт малтмал зэрэг томоохон хамтын ажиллагааны төслийн хэрэгжихийг дагаж, Монгол Оросын хооронд шинэ нэг ээлжийн эдийн засаг худалдааны хамтын ажиллагааны оргил үүсэх болно.

Хоёр Хятад Монголын харилцаа

Хоёр талын хамтын чармайлгаар, Хятад Монголын харилцаа тасралтгүй бэхжин хөгжиж байна. Энэ жил Хятад Монгол стратегийн түншлэлийн харилцаа байгуулав. Хоёр талын эдийн засаг худалдаа харилцан хөнгөлөлттэй харилцан ашигтай, Хятад орон олон жилийн турш Монгол улсын хамгийн том худалдааны түнш болон хамгийн том хөрөнгө оруулагч улсын байр сууриа хадгалсаар ирэв.

1. Улс төрийн харилцан итгэлцэл гүнзгийрэв

2009 онд хоёр улс Хятад Монголын дипломат харилцаа байгуулсан 60 жилийн ойг өвтэгш ихээр тэмдэглэж, 2010 онд хоёр улсын харилцаа шинэ нэгэн жаранд дэвшин орж, гүнзгийрүүлэн хөгжүүлэх чухал тохиол тохиогоод байна. Сүүлийн хоёр жилд, хоёр талын лидерууд удаа дараа харилцан айлчилж, байнга харилцаж байгаа нь хоёр талын харилцааны хөгжилд чухал үүрэг гүйцэтгэж байна.

2010 оны 4-р сарын сүүлч 5-р сарын эхээр, Монгол улсын ерөнхийлөгч Ц.Элбэгдорж Хятадад төрийн айлчлал хийж байгаа хугацаанд, хоёр тал чухал чухал хамтын танилтад хүрч, хоёр орны харилцааны гүнзгийрэн хөгжихөд бат бэх суурийг тавьсан байна.

2010 оны 6-р сарын 1-2-ны өдөр, Вэнь Жябао ерөнхий сайд урилгаар Монгол улсад айлчлав. Тэрээр Монгол улсын ерөнхий сайд С.Батболдттой хэлэлцээ хийхдээ Хятад Монгол хоёр тал бодитой арга хэмжээ авч, эдийн засаг худалдааны хамтын ажиллагааг гүнзгийрүүлж, уул уурхай ашигт малтмалын олборлолт, дэд бүтцийн бүтээн байгуулалт, банк санхүу гурвыг дэмжсэн хамтын ажиллагааг идэвхтэй ахиулах хэрэгтэй гэжээ. Хэлэлцээний дараа хоёр тал банк санхүҮ зээл, гаалийн хамтын ажиллагаа, ашигт малтмал болон цөмийн эрчим хүчийг нээн хөгжүүлэх, эрдмийн зэрэг цолын диплом зэрэг салбарын 
9 бичиг материалд гарын үсэг зурсан байна.

2011 оны 6-р сарын дундуур, Монгол улсын ерөнхий сайд С.Батболд Хятадад айлчилсан байна. Энэ удаагийн айлчлалын чухал агуулга нь Хятад Монголын хэлэлцээд удсан Хятад Монголын найрамдалт хөршийн харилцан итгэлцсэн түншлэлийн харилцааг стратегийн түншлэлийн харилцаа болгох асуудлыг шийдвэрлэсэн байна. Энэ нь Хятад Монголын харилцаа дахин нэг шинэ шатанд ахисныг харуулж байна.

2. Эдийн засаг худалдааны харилцаа тасралтгүй өргөжиж байна

Худалдаа дараалан шинэ шатанд ахив. 2010 онд Монгол улсын БНХАУ-тай хийсэн худалдааны нийт хэмжээ 3.434 тэрбум ам.долларын шинэ рекордын амжитад хүрч, өнгөрсөн оны мөн үеийнхээс 78.5\% өсч, экспорт 2.45 тэрбум ам.долларт хүрч, өнгөрсөн оны мөн үеийнхээс 75.8\% өсөв. Импорт 986 сая ам.долларт хүрч, өнгөрсөн оны мөн үеийнхээс 85.4\% өсчээ. 2010 онд Монгол Хятадын худалдааны хэмжээ Монголын гадаад худалдааны нийт хэмжээний 55.56\%-ийг эзлэв. 1999 оноос нааш, Хятад 12 жил дараалан Монгол улсын хамгийн том худалдааны түнш, мөн ч хамгийн том экспортлогч улс болсоор иржээ.

Монгол улсын Ашигт малтмалын газрын тоо баримтаас харвал, 2009-2010 онд, Монгол улсын ашигт малтмалын бүтээгдэхүүнийг голдуу Хятадад борлуулсан байна. Монголын экспортлосон 9 том төрлийн ашигт малтмалын бүтээгдэхүүнээс зэсийн баяжмал, нүүрс, нефть, төмрийн хүдэр, цайрын хүдэр, цахилгаанаар задалсан зэс зэрэг 6 төрлийн бүтээгдэхүүн нь 100\% Хятадад экспортлож байна.

Хөрөнгө оруулалтын салбарыг боловсронгуй болгох шаардлагатай. 1998 оноос хойш Хятадаас Монголд оруулж байгаа хөрөнгө нь 13 жил дараалан тэргүүн байр эзэлж ирэв. Монгол улсын Гадаадын хөрөнгө оруулалтын газрын тоо баримтаас харвал: 2009 онд, Хятадын Монгол улсад хөрөнгө оруулж байгаа аж ахуйн нэгж 4900 гаруй байж, хөрөнгө оруулалтын хэмжээ 2.29 тэрбум ам.долларыг давж, Монголд оруулж байгаа гадаадын хөрөнгийн 60\%-ийг эзэлсэн байна. Хятадын хөрөнгө оруулалттай аж ахуйн нэгжүүд голдуу Монгол улсын уул уурхай, газрын тос, хоол ундаа, барилга барилгын материал, малын ашиг шимийг боловсруулах, мэдээлэл холбооны технологи болон үйлчилгээний 
салбар болно. Гэтэл, Монгол улсын Хятадын худалдааны ерөнхий нийгэмлэг болон Монголын эрдэмтдийн нотолсноор, хэрэг дээрээ Монголд жинхэнэ ажил эрхэлж байгаа Хятадын хөрөнгө оруулалттай аж ахуйн нэгж дөнгөж 1000 гаруйхан байж, Монголд хөрөнгө оруулаад амжилтад хүрсэн Хятадын том аж ахуйн нэгж тоотой хэдхэн байна. Сүүлийн хоёр жил, Хятадын Монголд оруулж байгаа хөрөнгийн хэмжээ их биш, 2010 онд Хятадын Монголд оруулсан хөрөнгө өнгөрсөн оны мөн үеийнхээс 20\% 5 буурсан байна. Хятадын Монголд оруулж байгаа хөрөнгийн тоо буурсан нь, 2008-2009 оны банк санхүүгиййн хямралын хүчин зүйлээс гадна бас дараах шалтгаан буй. Хятадын тал: Монголын зах зээлийг гүйцэд судлаагүйгээр багшралдан хөрөнгө оруулж, замбраагүй өрсөлдөж, Монголд байгаа Хятадын аж ахуйн нэгжүүдийн ихэнх нь хүчин чадалгүй жижиг оврын аж ахуйн нэгж, ажилтных нь боловсрол аанай байдаг. Монголын тал: Хятадын хөрөнгө оруулалттай аж ахуйн нэгжийн технологи хоцронгуй, барилгын чанар муу, байгаль орчныг ноцтой бохирдуулж, татвар бага төлж, ил тод биш гэж гоморхож байна. Ииймээс, Хятад Монгол хоёр тал хөрөнгө оруулалтын салбарт ойлголцон зөвшилцөж, хоёр орны хөрөнгө оруулалтын харилцан ашигтай хамтын ажиллагааг түргэн боловсронгуй болгох хэрэгтэй.

Монгол улсын үүрдийн хөрш бол БНХАУ болон ОХУ

Дээр ярьсанчлан, Монгол улс нь хоёр хөрштэйгөө салшгүй нягт харьцаатай байдаг. Монгол Оросын стратегийн түншлэлийн харилцаа нь улс төр, эдийн засаг, цэрэг дайн зэрэг салбарт гүнзгийрэн хөгжиж байна. Монгол Хятадын найрсаг хөршийн харилцан итгэлцсэн түншлэлийн харилцаа нь стратегийн түншлэлийн харилцаа болж ахисан байна. Шинээр засвар оруулсан “Гадаад бодлогын үзэл баримтлал”-д ОХУ болон БНХАУ-тай найрсаг хөршийн найрамдалт харилцаа хөгжүүлэхийг Монгол улсын гадаад бодлогын тэргүүлэх чиглэл болгосон байна. Батлууштай нь, цаашдын маш урт хугацаанд Монгол улс мөн БНХАУ, ОХУ-тай найрсаг хөршийн найрамдалт харилцаагаа хөгжүүлж, “Олон тулгуурт”, тэнцвэртэй гадаад харилцааны хэлбэрээр үндэсний аюулгүй байдалд ашигтай орчныг байгуулах болно. Бусад улсуудын хүчин чадал яаж хүчирхэг байсан ч, цөм Монгол улсын жинхэнэ “Гуравдагч хөрш” болж чадахгүй, тэгэх мөртлөө Монгол улс эдийн засаг, далайд 
гарах гарцын талаар цөм хоёр хөршөөсөө салчих боломжгүй юм. Иймээс, Монгол улсын оршин тогтнож хөгжих олон улсын хүчин чадал нь эцэстээ зөвхөн үүрдийн хөрш улс-БНХАУ болон ОХУ-аас ирэлтэй, энэ бол Монгол улсын геополитикоос шийдвэрлэгдсэн юм.

(1)Лян Шюй: “Монгол: Орос Монгол цэргийн хамтын ажиллагаагаа сэргээж, Орос100 сая ам.долларын тоноглол нийлүүлэх гэж байна", http://www.huanqiu.com 2008/04/12.

(2) “Орос, Монголтой цэргийн хамтын ажиллагаагаа өргэтгөх гэж байна”, RUSNEWS.CN 2008/05/21.

(3)Монгол улсын армийн сонин “Соёмбо”, 2010 оны 9-р сарын 9-ний мэдээ.

(4)Монгол улсын Гаалийн ерөнхий газар “Монгол улсын гадаад худалдааны мэдээ”, 2010 ㅂ. № 12.

(5)Монгол улсын “Өнөөдөр” сонин,2010оны12-р сарын 6-ны мэдээ. 